\title{
Efficacy of Sodium Tetrathiocarbonate and Propiconazole in Managing Armillaria Root Rot of Almond on Peach Rootstock
}

James E. Adaskaveg, Assistant Professor, Helga Förster, Staff Research Associate. Department of Plant Pathology, University of California, Riverside 92521; Layne Wade, Research Assistant, David F. Thompson, Research Assistant, Department of Plant Pathology, University of California, Davis 95616; and Joseph H. Connell, Farm Advisor, University of California Cooperative Extension, Butte County, Oroville 95965

\begin{abstract}
Adaskaveg, J. E., Förster, H., Wade, L., Thompson, D. F., and Connell, J. H. 1999. Efficacy of sodium tetrathiocarbonate and propiconazole in managing Armillaria root rot of almond on peach rootstock. Plant Dis. 83:240-246.

The efficacy of sodium tetrathiocarbonate (STTC or Enzone 31.8\%, a liquid formulation that releases carbon disulfide) and the demethylation inhibiting (DMI) fungicide propiconazole (Alamo 1.1EC) was evaluated for management of Armillaria root rot of almond grown on Lovell peach rootstock. After 12 months, pre-/post-plant STTC (189 liters of 3,850 and 500 $\mathrm{mg} /$ liter $/ 3 \mathrm{~m}^{2}$ treatment site, respectively) or tarped pre-plant methyl bromide (Dowfume $98 \%$, $454 \mathrm{~g}$ a.i. $\left./ 3 \mathrm{~m}^{2}\right)$ soil fumigation treatments significantly $(P<0.05)$ reduced the recovery of $\mathrm{Ar}$ millaria mellea from naturally infected root segments at 0.3 and $1.2 \mathrm{~m}$ soil depths, compared with control sites. Tarped methyl bromide treatments eradicated the fungus from infested root segments at both depths; however, nontarped sites significantly reduced the recovery only at the $1.2 \mathrm{~m}$ depth. Pre-plant STTC (189 liters of 3,850 mg/liter/3 $\mathrm{m}^{2}$ ) reduced the recovery of the fungus but was not as effective as the pre-/post-plant STTC treatment. Recovery of the fungus in post-plant treatments with STTC (189 liters of $\left.500 \mathrm{mg} / \mathrm{liter} / 3 \mathrm{~m}^{2}\right)$ was not significantly $(P>$ 0.05 ) different from control sites. Additionally, mortality of almond tree replants from phytotoxicity was significantly higher in post-plant applications of STTC, compared with the other treatments or with the control trees. A gel formulation of $31.8 \%$ STTC $(1,800 \mathrm{ml}$ of $318,000 \mathrm{mg}$ of STTC per liter per tree stump) applied in wells that were drilled into tree stumps eradicated the fungus from trunk and primary roots but not secondary or tertiary roots, whereas liquid formulations of STTC and metam-sodium (Vapam - 32.7\% sodium $N$-methyldithiocarbamate) eradicated the fungus from only trunks but not roots. Treatments with STTC (189 liters of 500 $\mathrm{mg} / \mathrm{liter} / 3 \mathrm{~m}^{2}$ ) were not effective in preventing mortality of A. mellea-infected, mature, 7- to 8year-old almond trees. Propiconazole (Alamo 1.1EC) was shown to be toxic to mycelial growth of $A$. mellea grown on potato dextrose agar with an $\mathrm{EC}_{50}$ value of $0.15 \mathrm{mg} / \mathrm{liter}$. Therapeutic, passive injections of propiconazole into 7- to 8-year-old almond trees (Lovell peach rootstock) were successful in reducing mortality of infected trees during two growing seasons, compared with infected control trees treated with water.
\end{abstract}

Additional keyword: fungicides

Armillaria root rot caused by Armillaria mellea (Vahl: Fr.) P. Kumm. occurs on a wide range of hosts including Prunus spp. and other species of tree fruit and nuts crops $(19,20)$. It is a lethal disease of Prunus tree crops in the Central Valley of California. Shoestring root rot and oak root rot (18) are other names of the disease. Symptoms include poor shoot growth, premature yellowing and dropping of leaves, dieback of branches, and death of trees. Three diagnostic signs of the fungus are (i) white, fan-shaped, mycelial plaques that are formed between the bark and

Corresponding author: James E. Adaskaveg E-mail: jim.adaskaveg@UCR.edu

Accepted for publication 30 November 1998.

Publication no. D-1999-0111-02R

(C) 1999 The American Phytopathological Society wood, (ii) dark brown, rootlike mycelial strands called rhizomorphs that are associated with plant roots, and (iii) mushrooms or basidiocarps of the fungus that commonly occur in clusters around the base of the tree trunk (13). Mushrooms are usually produced between October and February in California.

The fungus attacks roots of plants, killing the cambium and degrading woody tissue $(23,26)$. The fungus spreads root to root by rhizomorphs or by mycelium through root contact. Rhizomorphs are the principal agents of infection that can penetrate directly through the bark of roots (23). In fruit tree production in California, as well as in forest trees, basidiospores of the fungus are not considered a major source of infection and their role in the epidemiology of the disease is considered limited $(18,22)$. The fungus causes a white rot of wood, degrading all major components of wood cell walls including cellu- lose, hemicellulose, and lignin (13), and survives on dead roots remaining in the soil after tree removal $(23,25)$.

In the past, resistant rootstocks and preplant soil fumigation have been the most effective control practices for Armillaria root rot. Resistant peach and plum rootstocks such as Mariana 2624 or Myrobalan 29-C have been used with Prunus spp. and offer a practical method of control $(2,21)$, but trees grafted to plum rootstocks are generally slower growing and dwarfed. Fumigants reduce inoculum of the fungus but eradication is rarely achieved. Fumigants evaluated against $A$. mellea have included methyl isothiocyanate (Vorlex), metam-sodium (Vapam), chloropicrin, methyl bromide, and the explosive carbon disulfide $(6,8,10,14-16)$. Application methods previously used include treatment of soil (15) or treatment of stumps (6) in agricultural or forest ecosystems, respectively. Metam-sodium and chloropicrin have not been used in soil fumigations for Armillaria root rot because penetration into soil is difficult to achieve with these fumigants.

Due to environmental concerns about methyl bromide and worker safety issues during application of carbon disulfide, alternative, nonexplosive, environmentally safe materials need to be evaluated for the control of Armillaria root rot. One alternative compound is sodium tetrathiocarbonate (STTC). This compound is formulated as Enzone, was first manufactured by Unocal Corp., Chemical Division, and currently is the product of Entek, Inc. The compound is a nonexplosive liquid formulation that degrades to carbon disulfide. Twelve and one-half percent of the product's labeled active ingredient STTC or $192 \mathrm{~g} /$ liter is converted to carbon disulfide. Based on manufacturer's recommendations, STTC can be used at high concentrations as a pre-plant fumigant or at low concentrations as a post-plant treatment possibly without causing phytotoxicity to growing plants at application sites.

Another alternative to the use of fumigants or a treatment to be used in combination with fumigants would be systemic fungicides. Hagle and Shaw (10) have reviewed potential chemical treatments for Armillaria root rot, including protectants, eradicants, and curatives. Hexaconazole, flutriafol, and fenpropidin have suppressed 
growth of A. mellea in vitro (24); however, no systemic fungicides have proven effective in the management of Armillaria root rot in the field. Propiconazole (Alamo 1.1EC) is a systemic fungicide that has been evaluated (1) and labeled for use for control of oak wilt in Texas. Although this fungus does not cause a root rot like $A$. mellea, it colonizes the vascular system and is difficult to control without the use of systemic fungicides. Potentially, propiconazole could protect from or suppress infections of Armillaria root rot in tree fruit orchards.

The objectives of this study were to evaluate STTC as an alternative soil fumigant to methyl bromide for reducing the recovery of $A$. mellea from infected peach (Prunus persica (L.) Batsch) root segments; to determine if direct stump treatments of infected almond (P. dulcis (Mill.) D. Webb)-peach rootstock trees eradicated the fungus from root systems; to evaluate the efficacy of STTC applications in preventing mortality of trees infected with Armillaria root rot; and to evaluate the in vitro toxicity of the systemic fungicide propiconazole to A. mellea and to determine the efficacy of trunk injections with the compound for suppressing Armillaria root rot of almond on peach rootstock in California.

\section{MATERIALS AND METHODS}

Isolation and identification of Armillaria spp. For isolation of Armillaria spp. from roots, root segments were broken open and wood was excised with a sterile razor blade and placed on $2 \%$ malt extract agar containing $10 \mathrm{mg}$ of benomyl (Benlate 50WP; DuPont, Wilmington, DE) per liter, $100 \mathrm{mg}$ of streptomycin per liter, and $2 \mathrm{ml}$ of $25 \%$ lactic acid per liter (BSM). Basidiocarps of the fungus were collected from three infection centers in the commercial orchard in Butte County, CA, in late December and early January. Cultures were identified following cultural characteristics described by Nobles (17). For species identification, basidiocarps were identified morphologically (3). Additionally, mating-type studies were conducted to determine the species of Armillaria (9). For this, four single-spore isolates for each of the three collections were retrieved and pairings of isolates were done with four tester strains of each North American Biological Species (NABS). Isolates were also sent to the University of Minnesota and the USDA Forest Products Laboratory in Madison, WI, for confirmation of species identification by the same methods (9).

In vitro toxicity of carbon disulfide and sodium tetrathiocarbonate. Almond branch segments $(2 \mathrm{~cm}$ long $\times 1 \mathrm{~cm}$ in diameter) were placed on pieces of autoclaved aluminum foil $(2 \times 1 \mathrm{~cm})$ on the surface of 2-week-old cultures of A. mellea from almond (isolate 335 or 346 ) grown on potato dextrose agar (PDA) and incubated for 4 weeks. Branch segments were removed from cultures, placed either directly into $50 \mathrm{ml}$ of an aqueous dilution of $31.8 \%$ liquid formulation of STTC (Enzone; Entek, Sacramento, CA) or in an open plastic petri dish lid floating on the surface of 50 $\mathrm{ml}$ of the fumigant in a sealed, 2-liter canning jar. Rates of STTC were calculated based on the label's active ingredient of the fumigant formulation (specific gravity 1.2), whereas rates of carbon disulfide were calculated based on $12.5 \%$ generation of $\mathrm{CS}_{2}$ from the liquid STTC formulation. Colonized branch segments were exposed to $4,000 \mathrm{mg}$ of STTC per liter or 2,000 and $4,000 \mathrm{mg}$ of $\mathrm{CS}_{2}$ per liter for 2, 3, 4, or 5 days at $25^{\circ} \mathrm{C}$. Submerged branch segments were removed and rinsed three times with distilled water ( 1 min per rinse) and were placed onto acidified malt extract agar containing $10 \mathrm{mg}$ of benomyl per liter. Gaseous fumigated segments were transferred from the fumigation chamber directly onto benomyl-amended, acidified malt extract agar. Petri dishes with treated segments were then incubated for 7 days at $25^{\circ} \mathrm{C}$ and evaluated for growth of $A$. mellea. Percent recovery of the fungus from treated branch segments was calculated based on the number of segments with growth of the fungus out of the total treated. Percent reduction was determined by subtracting percent recovery from 100 . The experiment was conducted twice; three replications of 10 branch segments were used for each chemical rate evaluated, and two isolates of $A$. mellea were used. Data were transformed $\left(\log _{10}\right)$ and analyzed by the analysis of variance, regression, and general linear model (GLM) procedures of SAS 6.12 (SAS Institute, Cary, NC).

Site selection for field experiments and soil characterization. Test plots were established at two locations: a commercial orchard in Butte County where $10 \%$ of a 50-acre block of trees had Armillaria root rot; and an experimental research farm of the Department of Plant Pathology, University of California, Davis, with no history of Armillaria root rot. Soil moisture at a depth of $0.3 \mathrm{~m}$ was measured gravimetrically and $\mathrm{pH}$ was determined by standard procedures (5) just prior to fumigation treatments. In the commercial orchard, experiments were conducted in Armillaria root rot infection centers. Trees that had died in the previous growing season were identified and they were removed prior to implementation of experimental treatments in the late fall season. Roots of removed trees were sampled and isolations for $A r$ millaria spp. were done in the laboratory.

Field fumigation studies with infested root segments. Approximately $200 \mathrm{seg}$ ments $(2.0 \mathrm{~cm}$ mean diameter, 1.25 to 2.5 $\mathrm{cm}$ diameter $\times 15$ to $18 \mathrm{~cm}$ length) were cut from roots obtained from almond trees that were naturally infested with A. mellea. The segments were stored at 1 to $3^{\circ} \mathrm{C}$ for approximately 3 weeks. Isolations were made as previously described to verify the presence of the fungus. Two root segments were tied $0.9 \mathrm{~m}$ apart to a stainless steel wire. For burial of the root segments, random sites were selected in the experimental orchard, whereas in the commercial orchard sites were chosen where dead infested trees had been removed. Two holes at each treatment site were dug with a tractor-mounted soil auger. Pairs of root segments, attached to the stainless steel wire, were lowered down into each hole 0.3 and $1.2 \mathrm{~m}$ deep from the soil surface, and the holes were refilled with soil. The end of each wire was tied to an iron stake. Root segments were buried in six replications of each fumigation treatment prior to pre-plant treatments. A liquid formulation of Enzone (31.8\% STTC) was used for soil treatments. Treatments were as follows: pre-plant STTC at 3,850 mg/liter (189 liters $/ 3 \mathrm{~m}^{2}$ treatment site); post-plant STTC at $500 \mathrm{mg} /$ liter $\left(189\right.$ liters $/ 3 \mathrm{~m}^{2}$ ); pre-/postplant STTC; and pre-plant methyl bromide (Dowfume 98\%, $454 \mathrm{~g}$ a.i./3 $\mathrm{m}^{2}$ ), and water drenches as control treatments. Preplant treatments were done in December and post-plant treatments were done the following May.

Pre-plant methyl bromide was applied by a commercial applicator at each site with a soil injector that placed the fumigant at a depth of $45 \mathrm{~cm}$. No coverings were used over the treated soil surface in the commercial orchard, whereas a plastic tarp was used in the experimental orchard. For pre-plant applications of STTC, a $3 \mathrm{~m}^{2}$ $\times 0.5 \mathrm{~m}$ basin was prepared at each replant site. Within 2 days of basins being prepared, a total of $5 \mathrm{~cm}$ of water was applied with sprinkler irrigation or from rain to settle the soil in each basin. At the time of the STTC treatment, 378 liters of water was applied to each site. An aqueous solution of the fumigant $(3,850 \mathrm{mg}$ of STTC per liter) was prepared and 189 liters of this solution was applied to each site. Buried root segments from each treatment site were removed after 12 months and evaluated for survival of Armillaria spp. The study was done once in each of the two orchards. Data were analyzed as a splitplot design for fumigation treatment and either root segment size or depth by the GLM and least significant difference (LSD) mean separation procedures of SAS 6.12 .

Survival of replant trees and phytotoxicity of soil fumigation treatments. The same two orchards and the same fumigation sites were used to determine the survival of replant trees and the phytotoxicity of pre- and post-plant fumigation treatments. Pre-plant treatments with STTC or methyl bromide were carried out in December as described in the previous section. In February, 1 week before planting, basins used for the STTC drench treatment were leveled and allowed to set- 
tle. Almond trees (Peerless, Carmel, or Butte) on Lovell peach rootstock were replanted into the fumigated basins in each orchard. After planting, soil from the fumigation treatment was used to refill the planting holes. Post-plant treatments were done the following May as described above. Ten months after the pre-plant treatments ( 8 months after planting), survival and health of trees were evaluated on nine single-tree replications for each treatment and orchard. Phytotoxicity of fumigation treatments was evaluated on the following scale: $0=$ healthy; $1=$ chlorotic leaves; 2 = chlorotic leaves and thin canopy; 3 = thin canopy and dieback; and $4=$ tree death. Trees that died were removed and $10 \mathrm{~cm}$ of root tissue was collected from three of the primary roots from each tree and plated onto BSM as described previously. Percent survival and phytotoxicity rating data were analyzed to compare treatments for each experiment by the GLM and LSD mean separation procedures of SAS.

Evaluation of STTC treatments of living, diseased, almond trees. Living, 7to 8-year-old mature trees that showed symptoms of Armillaria root rot and that bordered infection centers were selected at random in the commercial orchard. The fungus was isolated from root samples as previously described. In May, a soil drench was made applying STTC $(500 \mathrm{mg} / \mathrm{liter}$; 189 liters $/ 3 \mathrm{~m}^{2}$ ) in $3 \mathrm{~m}^{2}$ basins around 10 infected trees. Water was applied to basins around 10 control trees. Trees were rated before and 5 months after treatment with

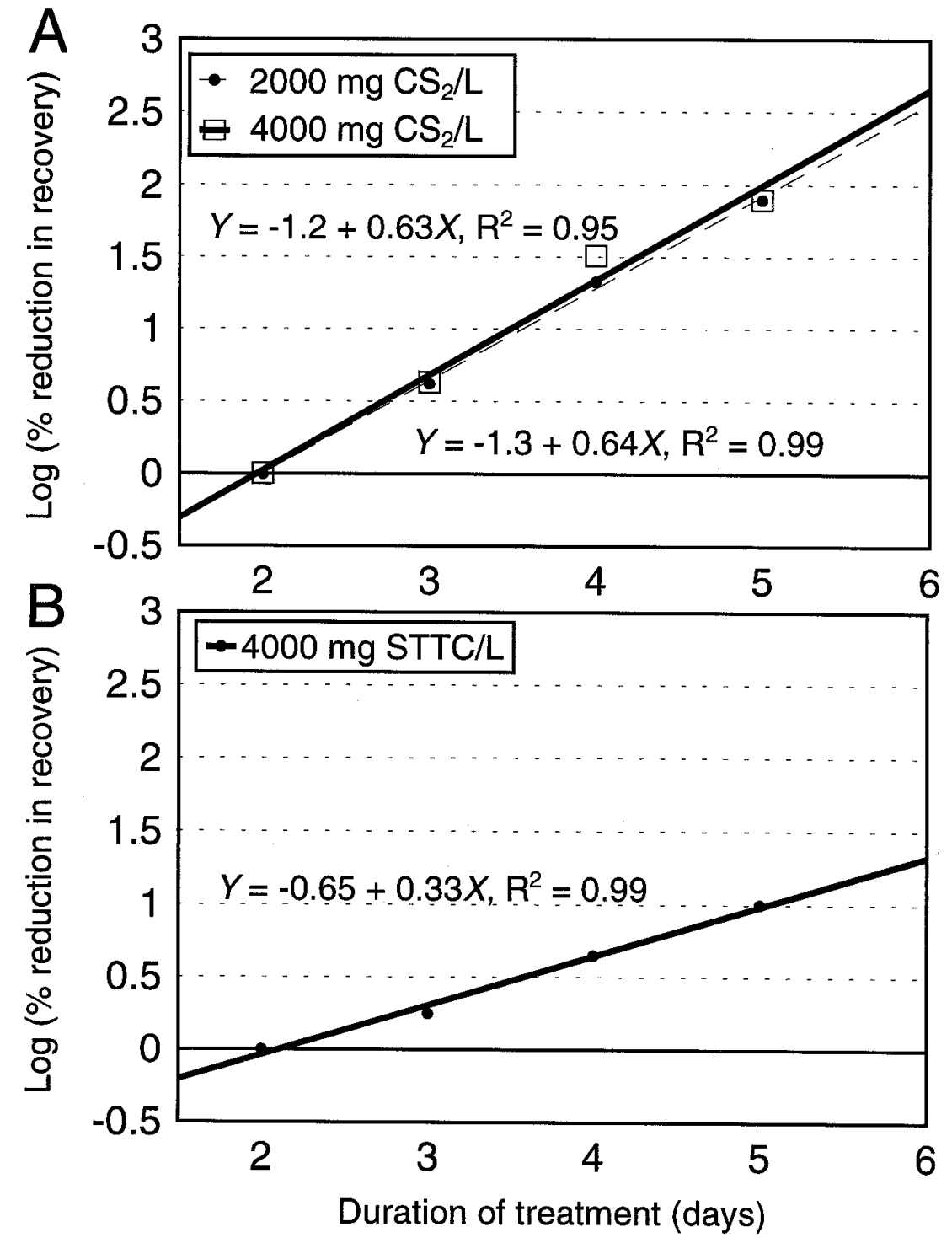

Fig. 1. Regressions of mean $\log _{10}$ percent reduction in the recovery of Armillaria mellea from laboratory-inoculated almond branches on duration $(2,3,4$, and 5 days) of treatment with sodium tetrathiocarbonate (STTC). Sterilized almond branch pieces $(2.0$ long $\times 1.0 \mathrm{~cm}$ in diameter) were placed on potato dextrose agar cultures of A. mellea for 4 weeks. Branches were (A) fumigated with gaseous $\mathrm{CS}_{2}(2,000$ or $4,000 \mathrm{mg} /$ liter) generated from STTC and vented, or (B) submerged directly in STTC $(4,000 \mathrm{mg} / \mathrm{liter})$ and rinsed; then they were plated on malt extract agar. Recovery was evaluated after 7 days of incubation on malt extract agar. the following disease severity scale: $0=$ healthy; $1=1$ to $25 \%$ dieback; $2=26$ to $50 \%$ dieback and yellowing of leaves; $3=$ 51 to $75 \%$ dieback, yellowing of leaves, and some scaffold limbs dead; and $4=$ $>76 \%$ dieback, yellowing of leaves, or tree death. The experiment was done twice in two growing seasons in the commercial orchard. Data were analyzed by the GLM and LSD mean separation procedures of SAS.

Evaluation of fumigation treatments of infested tree stumps. Trees that had died in the previous growing season were cut down, leaving stumps approximately $40 \mathrm{~cm}$ high (approximately $20 \mathrm{~cm}$ in height from the soil surface). Stump diameter was recorded and volumes of stumps were estimated at approximately $6,000 \mathrm{~cm}^{3}(\mathrm{~V}=$ $\left.\Pi r^{2} h\right)$. Rates of fumigants were based on Filip and Roth (6). Eight evenly spaced vertical holes $(2.1 \mathrm{~cm}$ in diameter $\times 12 \mathrm{~cm}$ deep) were made with an electric drill, 2.5 to $3 \mathrm{~cm}$ from the outer bark into the transverse section of the stump. Drill bits were disinfested after each tree in a solution containing $400 \mathrm{mg}$ of sodium hypochlorite per liter (16 $\mathrm{ml}$ of bleach per liter). The holes were filled with formulated material of either (i) STTC liquid or gel formulation (Enzone 31.8\% STTC), (ii) metam-sodium (Vapam - $32.7 \%$ sodium $N$-methyldithiocarbamate), or (iii) water. The fumigants were poured into each of the wells $(225 \mathrm{ml}$ per well), bark corks were placed in each hole, and exposed wood of the stumps was sealed with a silicone sealant. After the sealant dried, polyethylene plastic bags were placed over the stumps, the edges of the bag were buried with soil, and strapping tape was wrapped around the bags and trunks. Stumps were removed after 11 months, measured, and cut in half. Roots were removed, sorted into primary (30 linear $\mathrm{cm}$ from trunk base), secondary (branch roots 60 linear $\mathrm{cm}$ from trunk base), and tertiary (branch roots 90 linear $\mathrm{cm}$ from trunk base) roots. For sampling, nine wood pieces $(1 \times 0.5 \times 0.2 \mathrm{~cm})$ were collected from areas of decayed wood of trunk and root tissues for each singlestump replication. Isolation of A. mellea was conducted as previously described with BSM. The experiment was done twice in two separate growing seasons and data were analyzed by the GLM and LSD mean separation procedures of SAS.

In vitro efficacy of propiconazole. Three isolates of A. mellea from almond $(335,346$, and 347) were used to determine the toxicity of propiconazole to mycelial growth on PDA. For this, PDA was made containing $10,1.0,0.1,0.01,0.001$, or 0.00 $\mathrm{mg}$ of propiconazole per liter formulated as Alamo 1.1EC (Novartis, Greensboro, $\mathrm{NC}$ ). Agar plugs (4 $\mathrm{mm}$ in diameter) of 2week-old cultures were transferred to fungicide-amended media. Each plate was sealed with Parafilm and incubated at $25^{\circ} \mathrm{C}$ in the light. Each treatment was done four 
times and measurements of colony diameter $(\mathrm{mm})$ were made weekly for 4 weeks. Values were corrected for plug diameter and percent growth reduction was determined at each concentration of the fungicide evaluated, compared with growth on nonamended medium. Experiments were done twice for each isolate of the fungus. Data were analyzed with the analysis of variance and regression procedures of SAS.

Therapeutic efficacy of propiconazole in the field. In the same commercial orchard, 10 almond trees (20.3 to $25.4 \mathrm{~cm}$ trunk diameter), confirmed to have Armillaria root rot as described above, were used for 2 successive years in this study and rated for their state of decline. Decline ratings were based on the disease severity scale described above. Therapeutic rates were calculated based on 0.4 liters per $\mathrm{cm}$ of tree trunk diameter. Five trees were treated with Alamo 1.1EC at a concentration of $440 \mathrm{mg}$ a.i./liter with a passive infiltration system and five control trees served as controls. For Alamo treatments, six medical intravenous (IV) bags each containing $1,500 \mathrm{ml}$ of the fungicide dilution were hung on scaffold branches around the trunk of the tree in June. Six 1 $\times 2 \mathrm{~cm}$ holes were made with an electric drill, $5 \mathrm{~cm}$ below the graft line at 13 to 15 $\mathrm{cm}$ intervals around the circumference of the trunk. Drill bits were disinfested after each tree with a $400 \mathrm{mg}$ of hypochlorite per liter solution made from $5.25 \%$ sodium hypochlorite $(16 \mathrm{ml} /$ liter). Plastic tygon hose connectors were inserted into the holes and connected to the IV bags with tygon tubing. After $24 \mathrm{~h}$, empty bags were removed and corks were inserted into drill holes. If bags were not empty, new drill holes were made and IV bags were reconnected and allowed to drain, as described previously. Trees were evaluated 5 months (October) after treatment. The experiment was repeated in the second growing season with the same treated trees. New trees were selected for the control. Data were analyzed by the analysis of variance and LSD mean separation procedures of SAS 6.12.

\section{RESULTS}

Isolation and identification of Armillaria spp. Isolates of Armillaria were readily obtained from infected root tissue. Based on morphology of basidiocarps and basidia lacking basal clamps, the fungus causing Armillaria root rot of almond in California was identified as A. mellea sensu stricto. Furthermore, mating-type and vegetative incompatibility studies demonstrated that fluffy, single-basidiospore cultures became crustose with tester strains of NABS VI (A. mellea sensu stricto). Single-basidiospore pairings with tester strains of other NABS groups did not produce crustose colonies. Species identification was confirmed by researchers at the University of Minnesota and the USDA Forest Products Laboratory in Madison, WI.

In vitro toxicity of carbon disulfide and STTC. In laboratory studies, high rates $(2,000$ and 4,000 $\mathrm{mg} / \mathrm{liter})$ and long exposure times $(120 \mathrm{~h})$ were necessary to reduce the recovery of the fungus from colonized branch segments fumigated with $\mathrm{CS}_{2}$ that was generated from liquid STTC. The regression of the mean logarithm of percent reduction in recovery of $A$. mellea from treated branch segments on the duration of fumigation with 2,000 and 4,000 $\mathrm{mg}$ of $\mathrm{CS}_{2}$ per liter was significant $(P<$ $0.05)$ and linear with $R^{2}$ values of 0.98 and 0.99 , respectively (Fig. 1A). STTC was less toxic to the fungus in submerged wood segments (Fig. 1B), compared with wood posed to the generated $\mathrm{CS}_{2}$ gas. The regression of the logarithm of percent reduction in recovery of A. mellea from treated branch segments on the duration of treatment with 4,000 mg of STTC per liter was significant $(P<0.05)$ and linear, with an $R^{2}$ value of 0.99 (Fig. 1B).

Site selection for field experiments and soil characterization. In the commersegments placed above the liquid and ex-

cial orchard, two main soil types, a heavy clay loam and a sandy loam, characterized the upper $1 \mathrm{~m}$ of the soil profile of fumigation treatment sites. Below $1 \mathrm{~m}$, soils were generally sandy to gravelly. Just prior to the pre-plant field fumigation studies, soil $\mathrm{pH}$ ranged from 6.32 to 6.58 and soil moisture was $16 \%$ by weight (field capacity) in soil samples from the commercial orchard. In the University of California, Davis, research plot, the soil type was consistently a clay loam, soil $\mathrm{pH}$ ranged from 6.8 to 7.2 , and soil moisture was $20 \%$ by weight (field capacity).

Field fumigation studies with infested root segments. For both experiments in commercial and experimental orchards, percent recovery of A. mellea from infested, buried root segments after 12 months was dependent on treatment $(P<$ 0.01 ); however, a significant interaction between treatment and depth of buried root segments $(P<0.05)$ on percent recovery of A. mellea was observed. Thus, data were sorted and analyzed by depth for each experiment (Fig. 2A, B). In the commercial orchard, where no covering was used for the methyl bromide treatment, only the pre-/post-plant STTC treatment at both soil

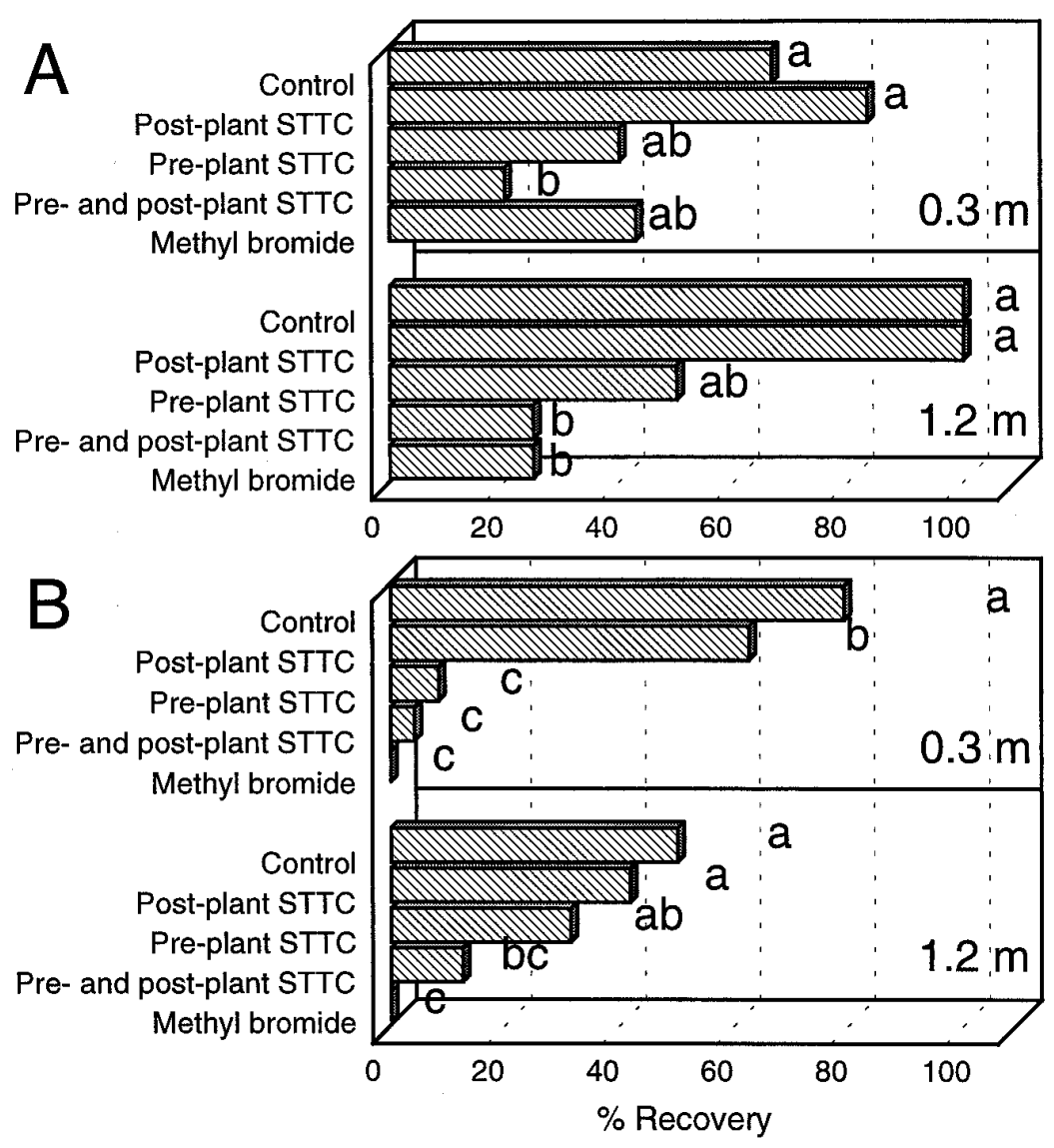

Fig. 2. Efficacy of pre-plant (189 liters of $3,850 \mathrm{mg} / \mathrm{liter}$ ) sodium tetrathiocarbonate (STTC), postplant STTC (189 liters of $500 \mathrm{mg} / \mathrm{liter}$ ), pre-/postplant STTC (same rates), with (A) nontarped preplant methyl bromide ( $454 \mathrm{~g}$ per site) in the commercial orchard or (B) tarped pre-plant methyl bromide (454 g per site) in the experimental orchard, as soil fumigation treatments for reducing the recovery of Armillaria mellea from buried (0.3 and $1.2 \mathrm{~m}$ deep), infested Lovell peach root segments after 12 months. 
depths significantly $(P<0.05)$ reduced the recovery of $A$. mellea from infested root segments, compared with the control (Fig. 2A), whereas methyl bromide significantly $(P<0.05)$ reduced the recovery only at the $1.2 \mathrm{~m}$ depth. The pre-plant STTC treatment reduced the recovery of $A$. mellea at both soil depths and formed an intermediate statistical group between the control and the pre-/post-plant STTC treatments. The post-plant STTC treatment was not significantly different $(P>0.05)$ from the control at both soil depths. In the experimental orchard, where a covering was used for the methyl bromide treatment, the pre-/postplant STTC and methyl bromide treatments significantly reduced percent recovery of A. mellea from root segments regardless of depth (Fig. 2B). At the $0.3 \mathrm{~m}$ depth, percent recovery of $A$. mellea from

Table 1. Percent survival of almond on Lovell peach rootstocks and phytotoxicity of soil fumigation treatments 10 months after pre-plant and 5 months after post-plant fumigation treatments

\begin{tabular}{lcccc}
\hline Treatment $^{\mathbf{x}}$ & Timing & No. of trees & Percent survival $^{\mathbf{y}}$ & Phytotoxicity rating $^{\mathbf{z}}$ \\
\hline Control & $\ldots$ & 17 & $100 \mathrm{a}$ & $0.1 \mathrm{~b}$ \\
Methyl bromide & Pre-plant & 18 & $100 \mathrm{a}$ & $0.2 \mathrm{~b}$ \\
STTC & Pre-plant & 18 & $83 \mathrm{~b}$ & $0.9 \mathrm{~b}$ \\
STTC & Post-plant & 18 & $50 \mathrm{c}$ & $2.6 \mathrm{a}$ \\
\hline
\end{tabular}

${ }^{\mathrm{x}}$ Fumigation treatments were as follows: pre-plant sodium tetrathiocarbonate (STTC), 189 liters per $3 \mathrm{~m}^{2}$ site at 3,850 mg/liter; post-plant STTC, 189 liters per $3 \mathrm{~m}^{2}$ site at $500 \mathrm{mg} /$ liter; methyl bromide at $454 \mathrm{~g}$ per site; and control.

y Percent survival was the percentage of trees alive of the total number of trees treated in two growing seasons (nine trees per year). Values followed by the same letter are not significantly different $(P>0.05)$ based on general linear model and least significant difference (LSD) mean separation.

${ }^{\mathrm{z}}$ Severity rating: $0=$ healthy; $1=$ chlorotic leaves; $2=$ chlorotic leaves and thin canopy; $3=$ thin canopy and dieback; and $4=$ tree death.

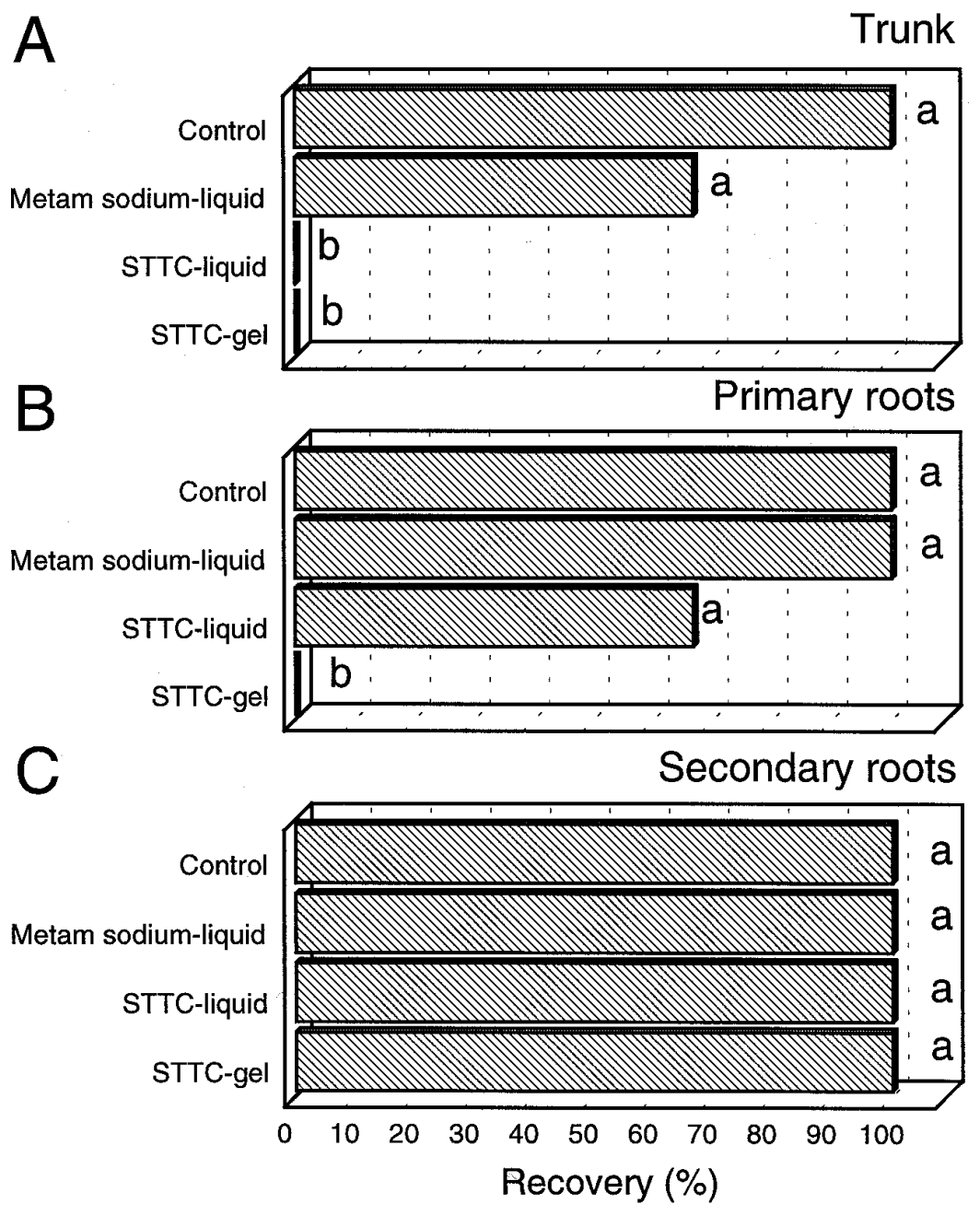

Fig. 3. Efficacy of stump fumigation treatments with sodium tetrathiocarbonate (STTC - liquid or gel formulations) or metam-sodium (liquid formulation) in reducing the recovery of Armillaria mellea from (A) trunk, (B) primary, and (C) secondary roots of Lovell peach rootstock. infested roots was also significantly $(P<$ $0.05)$ reduced in the pre-plant and to a lesser degree in the post-plant STTC treatments, compared with the control. At the $1.2 \mathrm{~m}$ depth, however, neither treatment significantly $(P>0.05)$ reduced the recovery of the fungus from the infested root segments, compared with the control treatment (Fig. 2B).

Survival of replant trees and phytotoxicity of soil fumigation treatments. Ten months after pre-plant treatments (5 months after post-plant treatments), percent survival of trees in pre-plant or postplant STTC-fumigated soil was significantly reduced $(P<0.05)$, compared with trees grown in soil fumigated with preplant methyl bromide or control trees (Table 1). No significant difference $(P>$ $0.05)$ was observed in a phytotoxicity rating of control and pre-plant (methyl bromide or STTC) treatments. In trees treated only with post-plant STTC, however, a significant increase $(P<0.05)$ in phytotoxicity rating was observed. In all root isolations, A. mellea was not recovered from trees that died.

Evaluation of STTC treatments of living, diseased, almond trees. Prior to treatment, average disease severity of trees was rated 1.7 and 1.8 for each growing season that the experiment was done and no significant differences $(P>0.05)$ were observed between designated trees. For both seasons, percent survival of mature trees treated with STTC (65\% survival) or water $(55 \%$ survival) was not significantly different $(P>0.05) 6$ months after treatment. Severity rating, however, was significantly reduced $(P<0.05)$ with the STTC treatment (1.75), compared with the control treatment (2.60).

Evaluation of fumigation treatments of infested tree stumps. After 1 year in both experiments, recovery of A. mellea was significantly $(P<0.01)$ reduced after fumigation of tree stumps; however, there was a significant interaction between treatment and tree tissue used for isolations $(P<0.05)$ of A. mellea. Thus, data were sorted and analyzed by tree tissue (Fig. 3A-C). Both STTC formulations eradicated $A$. mellea from trunks, but only the STTC gel formulation treatment eradicated the fungus from primary roots (Fig. 3A, B). Metam-sodium did not significantly reduce the recovery of $A$. mellea from trunk or primary roots (Fig. 3A, B). None of the fumigants eradicated the pathogen from secondary roots (Fig. 3C).

In vitro efficacy of propiconazole. Based on laboratory evaluations, propiconazole was inhibitory at $0.1 \mathrm{mg} / \mathrm{liter}$ and prevented fungal growth at $1.0 \mathrm{mg} / \mathrm{liter}$. Growth at $0.001 \mathrm{mg} / \mathrm{liter}$ was similar to that of the nonamended control. The model of the $\log _{10}$ of fungicide concentration on probit of the percent reduction of growth (Fig. 4) was significant $(P<0.05)$ and linear $\left(R^{2}=0.88\right)$. The equation was $Y=$ 
$-0.82+0.5 X$ and the $\mathrm{EC}_{50}$ was calculated as $0.15 \mathrm{mg} / \mathrm{liter}$. Mycelial growth occurred on the plug of inoculum at $1.0 \mathrm{mg} / \mathrm{liter}$; however, propiconazole was completely inhibitory at concentrations of $10 \mathrm{mg} /$ liter.

Therapeutic efficacy of propiconazole in the field. Therapeutic passive injections of propiconazole (440 mg/liter) were made into five 7- or 8-year-old almond trees (Lovell peach rootstock) infected with $\mathrm{Ar}$ millaria spp. On a rating of 0 to 4 (4 = death), mean disease severity (DS) ratings were 1.8 for treated and 2.0 for control trees prior to treatment $(P>0.1)$. After 5 months, all propiconazole-treated trees were alive (DS $=1.8$ ), whereas four of the five control trees were dead (DS = 3.6). In the second season, DS ratings were the same for both treated and the newly selected control trees (DS $=2.0$ ) prior to treatment. After 5 months, four of the five propiconazoletreated trees (DS $=2.5$ ) survived in the second season, whereas four of the five control trees died (DS $=3.8$ ). For both seasons, significant differences were observed between the two treatments for both mortality and disease severity (Table 2).

\section{DISCUSSION}

STTC formulated as Enzone is a nonexplosive liquid compound that releases carbon bisulfide as a break-down product when exposed to air. In the study presented here, we demonstrated for the first time the effectiveness of STTC for reducing the recovery of $A$. mellea sensu stricto from woody tree tissue in both laboratory and field studies. In laboratory studies, formation of $\mathrm{CS}_{2}$ from STTC was shown to reduce the recovery of $A$. mellea from woody tissue. Bliss (4) and Garrett (7) demonstrated that $\mathrm{CS}_{2}$ eradicated the fungus from woody tissue. In the latter study, Garrett (7) showed that A. mellea was eradicated from willow shoot segments with $207 \mathrm{mg}$ of carbon disulfide per liter after $72 \mathrm{~h}$ of

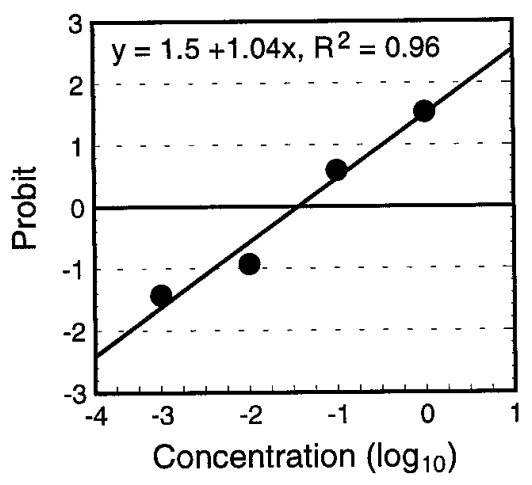

Fig. 4. Regressions of probit of percent growth reduction of Armillaria. mellea cultured on potato dextrose agar on concentration $\left(\log _{10}\right)$ of propiconazole $(0.001,0.01,0.1$, and $1 \mathrm{mg} /$ liter). Agar plugs (4 $\mathrm{mm}$ in diameter) containing mycelium of the fungus were transferred to fungicide-amended potato dextrose agar, incubated at $25^{\circ} \mathrm{C}$, and evaluated after 4 weeks. exposure. In our laboratory study, however, higher rates of CS2 (2,000 mg/liter) generated from liquid STTC and longer exposures $(120 \mathrm{~h})$ were necessary to reduce the recovery of the fungus from colonized branch segments. Although $\mathrm{CS}_{2}$ was not measured, this was probably due to the time required for the generation of $\mathrm{CS}_{2}$ from STTC. Matheron and Matejka (12) determined growth inhibitory rates of STTC to six Phytophthora spp. by submerging mycelial plugs directly in selected concentrations of STTC. In their study, growth of most Phytophthora spp. evaluated was completely inhibited at a rate of $2,450 \mathrm{mg}$ of STTC per liter after 5 days of incubation in amended media. In our study, exposure to STTC at $4,000 \mathrm{mg}$ per liter for 5 days in submerged wood segments was less toxic to the fungus, compared with wood segments placed above a liquid and exposed to the generated $\mathrm{CS}_{2}$ gas $(2,000$ $\mathrm{mg} / \mathrm{liter}$ ).

In field studies, pre-/post-plant treatments of STTC were effective in reducing the recovery of A. mellea from root segments buried at 0.3 and $1.2 \mathrm{~m}$ depths and were significantly more effective than post-plant STTC treatments. Efficacy of STTC decreased with soil depth in the high clay soil of the experimental orchard and only the pre-/post-plant STTC and methyl bromide treatments significantly reduced the recovery of the pathogen from roots at $1.2 \mathrm{~m}$ (Fig. 2B). A single, pre-plant application of STTC was only effective at the $0.3 \mathrm{~m}$ depth in the clay soil of the experimental orchard. The effectiveness of this treatment was statistically intermediate between pre-/post-plant STTC and the control at the $1.2 \mathrm{~m}$ depth of the experimental orchard and at both depths in the commercial orchard. Thus, two applications of STTC applied as pre- and postplant treatments were equivalent to methyl bromide in the commercial orchard at the $1.2 \mathrm{~m}$ depth and in the experimental orchard at the 0.3 and $1.2 \mathrm{~m}$ depths. Methyl bromide was used as a fumigation standard and this treatment was the most effective for reducing the recovery of the fungus from buried root segments in the experimental orchard, where treatment sites were tarped. This was also the only treatment in which the fungus was eradicated from the buried root segments. In the commercial orchard, where treatment sites were not tarped, methyl bromide was very effective in reducing the recovery of the fungus at the $1.2 \mathrm{~m}$ depth but not at the $0.3 \mathrm{~m}$ depth (Fig. 2A). Although the methyl bromide concentration was not measured in soil, volatilization of the fumigant into the atmosphere prior to reaching a toxic soil vapor pressure is the most likely explanation for lack of efficacy at the $0.3 \mathrm{~m}$ depth.

As only a post-plant treatment, STTC (500 mg of $\mathrm{CS}_{2}$ per liter) was mostly ineffective during the time period of sampling (i.e., 12 months) in these experiments. Furthermore, percent survival data indicated that the post-plant STTC treatment was phytotoxic to young, replanted trees (Table 1). Perhaps the lack of pre-plant fumigation and soil conditions such as temperature and moisture levels may predispose almond trees to injury when postplant applications of STTC are used.

Stump fumigation treatments were evaluated for the potential of eradicating the fungus from the root system of the tree before stumps were removed and root systems disturbed. In our study, fumigation of stumps with STTC as a liquid or gel formulation was ineffective in eradicating $A$. mellea. Filip and Roth (6), using fumigants such as carbon disulfide, chloropicrin, methyl bromide, and metam-sodium, successfully eradicated the fungus from stumps and primary roots of ponderosa pine in logged forests. In our study, only the STTC gel formulation eradicated the fungus from stump and primary roots, whereas none of the fumigants, including metam-sodium, eradicated the pathogen from secondary or tertiary roots. Differences in efficacy between our study and Filip and Roth's study could be attributed to differences between the tree species treated. Perhaps greater movement of the fumigant occurred within the conifer of their study than within the hardwood species used in our study. Lack of eradication from the secondary and tertiary roots of treated stumps limits the possible uses of this treatment in commercial orchards, where stumps are eventually removed and sites are prepared for re-planting.

Table 2. Therapeutic efficacy of propiconazole for management of Armillaria root rot in mature almond trees (Lovell peach rootstock) naturally infected with Armillaria mellea and evaluated 5 months after treatment

\begin{tabular}{|c|c|c|c|c|}
\hline Treatment $^{\mathrm{x}}$ & Formulation & Rate (mg a.i./liter) & Disease severity ${ }^{y}$ & Survival $(\%)^{\mathrm{z}}$ \\
\hline Propiconazole & Alamo 1.1EC & 440 & $2.1 \mathrm{a}$ & $90 \mathrm{a}$ \\
\hline Control & Water & $\ldots$ & $3.7 \mathrm{~b}$ & $30 \mathrm{~b}$ \\
\hline
\end{tabular}

${ }^{\mathrm{x}}$ Fungicide was applied in approximately 9 liters of water $(0.4$ liters per $\mathrm{cm}$ of tree trunk diameter $)$ with a passive, gravity-feed system. Applications were made in May and trees were evaluated in October. A total of 10 trees per treatment (five single-tree replications per year) were used in two growing seasons.

y Severity ratings were based on the following scale: $0=$ healthy; $1=25 \%$ dieback; $2=50 \%$ dieback and yellowing of leaves; $3=75 \%$ dieback and some scaffold limbs dead; and $4=$ tree death. The same scale was used for both pre- and post-treatment ratings.

${ }^{\mathrm{z}}$ Survival equals the percentage of trees that lived of the total trees treated and evaluated. 
Single-season, therapeutic treatments of infected mature trees with STTC were not phytotoxic but also were not effective in suppressing the decline or preventing the death of trees from Armillaria root rot. The use of STTC for eradicating the pathogen or preventing tree death when the tree is extensively colonized by A. mellea is not promising. Perhaps additional applications of STTC within a growing season would help to maintain tree survival, but these may not be practical.

In laboratory studies, propiconazole at a concentration of $0.15 \mathrm{mg} /$ liter inhibited mycelial growth of A. mellea by $50 \%$. At concentrations of $10 \mathrm{mg} /$ liter, the fungicide was completely inhibitory. Infected trees passively injected with the fungicide were kept alive for 2 years, whereas most of the control trees at similar stages of decline at the time of treatment died within 4 months in each year of the evaluation. Thus, therapeutic treatments with propiconazole were effective, at least in the short term, on trees with advanced symptoms of Armillaria root rot. Trees surrounding infection centers are likely to become infected over time. Thus, annual therapeutic treatments of trees surrounding infection centers prior to symptom development may be an effective management method of Armillaria root rot in commercial orchards.

In 1998, STTC as Enzone was registered for management of Armillaria root rot of almonds and may provide an effective alternative to the use of methyl bromide. Propiconazole as Break or Orbit 3.6EC is registered on stone fruit crops as a foliar treatment for management of brown rot (Monilinia spp.) and other diseases but not for Armillaria root rot. Additional residue studies are needed for registration for management of Armillaria root rot. Potentially, fumigation and systemic fungicide treatments could be utilized with resistant rootstocks in an integrated pest management strategy. Pre-plant fumigation treatments could be used to eliminate or reduce inoculum in the root zone of planting sites. Subsequently, as trees grow, applications of a systemic fungicide could be used to prevent infection of healthy trees as their roots grow beyond fumigated zones of soil and contact new sources of inoculum (e.g., old, infested roots). Thus, tree fruit growers may be able to replant into Armillaria spp. infection centers with minimal risk, and effectively manage the disease on almond.

\section{ACKNOWLEDGMENTS}

We would like to thank W. B. Bell and N. Phillips, Jr., for technical assistance in STTC applications, Keith Emerson and Les Heringer for cooperation in studies in the commercial orchard, P. Reyner and K. Conn for technical assistance in isolations of root samples, S. Garabedian and J. Vartanian for technical advice concerning STTC, R.A. Blanchette and H. Burdsall for confirmation of Armillaria species identification, and P. A. Mauk for reviewing this manuscript prior to submission for publication and providing editorial comments for improving the presentation of this research.

\section{LITERATURE CITED}

1. Appel, D. N., and Kurdyla, T. 1992. Intravascular injection with propiconazole in live oak for oak wilt control. Plant Dis. 76:1120-1124.

2. Beckman, T. G., Okie, W. R., Nyczepir, A. O., Pusey, P. L., and Reilly, C. C. 1998. Relative susceptibility of peach and plum germplasm to Armillaria root rot. HortScience 33:10621065.

3. Bérubé, J. A., and Dessureault, M. 1989. Morphological studies of the Armillaria mellea complex: Two new species, A. gemina and A. calvescens. Mycologia 81:216-225.

4. Bliss, D. E. 1951. The destruction of Armillaria mellea in citrus soils. Phytopathology 41:665-683.

5. Chapman, H. D., and Pratt, P. F. 1961. Methods of Analysis for Soils, Plants, and Waters. University of California, Division of Agricultural Sciences, Publ. No. 4034. Berkeley, CA.

6. Filip, G. M., and Roth, L. F. 1977. Stump injections with soil fumigants to eradicate Armillariella mellea from young-growth ponderosa pine killed by root rot. Can. J. For. Res. 7:226-231.

7. Garrett, S. D. 1957. Effect of a soil microflora selected by carbon disulphide fumigation on survival of Armillaria mellea in woody host tissues. Can. J. Microbiol. 3:135-149.

8. Godfrey, G. H. 1936. Control of soil fungi by soil fumigation with chloropicrin. Phytopathology 26:246-256.

9. Guillaumin, J.-J., Anderson, J. B., and Korhonen, K. 1991. Life cycle, interfertility, and biological species. Pages 10-20 in: Armillaria Root Disease. C. G. Shaw III and G. A. Kile, eds. United States Department of Agriculture, Forest Service, Agric. Handb. No. 691.

10. Hagle, S. K., and Shaw, C. G., III. 1991. Avoiding and reducing losses from Armillaria root disease. Pages 157-173 in: Armillaria Root Disease. C. G. Shaw III and G. A. Kile, eds. United States Department of Agriculture, Forest Service, Agric. Handb. No. 691.

11. LaRue, J. H., Paulus, A. O., Wilbur, W. D., O'Reilly, J. H., and Darley, E. F. 1962. Ar- millaria root rot fungus controlled with methyl bromide soil fumigation. Calif. Agric. $16: 8-9$.

12. Matheron, M. E., and Matejka, J. C. 1988. In vitro activity of sodium tetrathiocarbonate on sporulation and growth of six Phytophthora species. Phytopathology 78:1234-1237.

13. Morrison, D. J., Williams, R. E., and Whitney, R. D. 1991. Infection, disease development, diagnosis, and detection. Pages 62-75 in: $\mathrm{Ar}-$ millaria Root Disease. C. G. Shaw III and G. A. Kile, eds. United States Department of Agriculture, Forest Service, Agric. Handb. No. 691.

14. Munnecke, D. E., Kolbezen, M. J., and Wilbur, W. D. 1973. Effect of methyl bromide or carbon disulfide on Armillaria and Trichoderma growing on agar medium and relation to survival of Armillaria in soil following fumigation. Phytopathology 63:1352-1357.

15. Munnecke, D. E., Kolbezen, M. J., Wilbur, W. D., and Ohr, H. D. 1981. Interactions involved in controlling Armillaria mellea. Plant Dis. 65:384-389.

16. Munnecke, D. E., Wilbur, W. D., and Kolbezen, M. J. 1970. Dosage response of Armillaria mellea to methyl bromide. Phytopathology 60:992-993.

17. Nobles, M. K. 1965. Identification of cultures of wood-inhabiting Hymenomycetes. Can. J. Bot. 43:1097-1139.

18. Ogawa, J. M., and English, H. E. 1991. Diseases of Temperate Zone Tree Fruit and Nut Crops. University of California, Division of Agriculture and Natural Resources, Publ. 3345. Oakland, CA

19. Raabe, R. D. 1962. Host list of the root rot fungus, Armillaria mellea. Hilgardia 33:2588.

20. Raabe, R. D. 1979. Some previously unreported hosts of Armillaria mellea in California, III. Plant Dis. Rep. 63:494-495.

21. Raabe, R. D. 1979. Resistance or susceptibility of certain plants to Armillaria root rot University of California Division of Agricultural Sciences, Leafl. 2591.

22. Redfern, D. B., and Filip, G. M. 1991. Inoculum and infection. Pages 48-61 in: Armillaria Root Disease. C. G. Shaw III and G. A. Kile, eds. United States Department of Agriculture, Forest Service, Agric. Handb. No. 691.

23. Thomas, H. E. 1934. Studies on Armillaria mellea (Vahl.) Quél., infection, parasitism, and host resistance. J. Agric. Res. 48:187218.

24. Turner, J. A., and Fox, R. T. V. 1988. Prospects for the chemical control of Armillaria species. Bright. Crop Prot. Conf. Pests Dis. 1: 235-240.

25. Wilbur, W., Munnecke, D. E., and Darley, E. F. 1972. Seasonal development of Armillaria root rot of peach as influenced by fungal isolates. Phytopathology 62:567-570.

26. Zeller, S. M. 1926. Observations of infections of apple and prune roots by Armillaria mellea Vahl. Phytopathology 16:479-484. 